\title{
PORCN wt Allele
}

National Cancer Institute

\section{Source}

National Cancer Institute. PORCN wt Allele. NCI Thesaurus. Code C132190.

Human PORCN wild-type allele is located in the vicinity of Xp11.23 and is approximately $12 \mathrm{~kb}$ in length. This allele, which encodes protein-serine O-palmitoleoyltransferase porcupine protein, plays a role in post-translational modification of Wnt family proteins. Mutation of the gene is associated with focal dermal hypoplasia. 